Bartosz Smolik

ORCID: 0000-0001-7173-2389

Uniwersytet Wrocławski

\title{
Globalne systemy nawigacji satelitarnej. Przykład rywalizacji czy współpracy między mocarstwami?
}

DOI: $10.19195 / 1643-0328.25 .10$

Słowa kluczowe: systemy nawigacji satelitarnej, polityka kosmiczna, rywalizacja, Galileo, GPS

\section{Wprowadzenie}

Temat niniejszego artykułu wiąże się z zagadnieniem posiadania oraz budowy globalnych systemów nawigacji satelitarnej. W ciągu ostatnich kilkunastu lat problem stał się szczególnie aktualny. Powodem tego jest zarówno przyrost infrastruktury technicznej i rozmaitych aplikacji bazujących na nawigacji satelitarnej, jak i powiększająca się liczba państw i innych podmiotów aspirujących do posiadania własnych osiągnięć w tej dziedzinie. Przyczyny tego rosnącego zainteresowania mają charakter polityczny, ekonomiczny i militarny. Termin „globalny system nawigacji satelitarnej” (Global Navigation Satellite System - GNSS) jest łączony z trzema funkcjami: precyzyjne określanie pozycji, prędkości i czasu ${ }^{1}$.

Celem niniejszego artykułu jest odpowiedź na pytanie, czy mamy obecnie do czynienia z zacieśnianiem współpracy czy raczej rywalizacją w dziedzinie globalnych systemów nawigacji satelitarnej określanych skrótowo jako GNSS. Aby odpowiedzieć na to pytanie, w pierwszej części artykułu dokonam krótkiej charakterystyki czterech działających obecnie (lipiec 2018 r.) lub w najbliższej przyszłości globalnych systemów nawigacji satelitarnej. Wśród nich należy wymienić: amerykańskiego GPS-NAVSTAR, rosyjskiego GLONASS, europejskiego Galileo i chińskiego BeiDou. Uwzględnię przy tym genezę ich powstania oraz rolę, jaką odgrywają w polityce zagranicznej danego kraju. Niezbędne

1 Taką definicję przytacza rezolucja Zgromadzenia Międzynarodowej Organizacji Morskiej z 29 listopada 2001 r. - zob. Revised Maritime Policy and Requirements for a Future Global Navigation Satellite System (GNSS), Resolution A.915 (22), 29 listopada 2001, s. 11. Analogiczną definicję przytaczają specjaliści z dziedziny radionawigacji - zob. J. Narkiewicz, GPS $i$ inne satelitarne systemy nawigacyjne, Warszawa 2007, s. 9. 
będzie przy tym przypomnienie faktów dobrze znanych profesjonalistom z branż technicznych. Następnie przeanalizuję relacje pomiędzy Stanami Zjednoczonymi, Federacją Rosyjską, Unią Europejską i Chińską Republiką Ludową w kontekście współpracy i rywalizacji w obszarze GNSS.

Ze względu na ograniczenia objętościowe pominę autonomiczne systemy regionalnej nawigacji satelitarnej, jak indyjski IRNSS ${ }^{2}$. Nie uwzględnię także działających regionalnie systemów SBAS (czyli wspomagających często niedokładne pomiary GNSS), jak europejski EGNOS ${ }^{3}$ oraz działające w innych regionach świata WAAS, SDCM, GAGAN, MSAS, czy kończony obecnie przez Japonię QZSS ${ }^{4}$. Wiąże się z tym interesujące zagadnienie tzw. azjatyckiego wyścigu kosmicznego ${ }^{5}$. Z analogicznych względów zmuszony jestem także pominąć kwestie techniczne związane z GNSS, wyłączywszy wyjaśnienie znaczenia niektórych występujących w tekście terminów. Problematyka GNSS doczekała się już w języku polskim sporej liczby publikacji periodycznych i książkowych o charakterze technicznym. Dotychczasowa polska literatura politologiczna na temat GNSS jest stosunkowo skromna. Wyjątek mogą stanowić cytowane poniżej publikacje Irmy Słomczyńskiej i Pawła Turczyńskiego. Odnoszą się one jednak tylko do systemu Galileo. Wskazać można również niektóre artykuły Jakuba Ryzenki ${ }^{6}$.

Metodą badawczą przyjętą w niniejszym artykule jest analiza źródeł. Towarzyszyć jej będzie analiza porównawcza dotycząca zwłaszcza genezy powstania poszczególnych systemów. Dokonam zatem analizy treści dokumentów dwustronnych dotyczących współpracy w dziedzinie nawigacji satelitarnej - w pierwszej kolejności, uchodzącego za wzorcowe, porozumienia z Dromoland Castle z 2004, wspólnych oświadczeń w sprawie współpracy różnych systemów, rezolucji Parlamentu Europejskiego w sprawie europejskiej polityki kosmicznej. Przytoczę także raporty Międzynarodowego Komitetu do spraw Globalnych

${ }^{2}$ Indian Regional Navigation Satellite System — indyjski regionalny autonomiczny system nawigacyjny budowany w celu uniezależnienia się od systemów globalnych, w tym zwłaszcza GPS.

3 EGNOS (European Geostationary Navigation Overlay Service) - Europejski System Wspomagania Satelitarnego, określany pierwotnie jako GNSS-1. System transmituje za pośrednictwem dodatkowych satelitów orbitalnych i naziemnych stacji referencyjnych poprawki różnicowe GPS i GLONASS, dzięki czemu ich pomiar jest dokładniejszy. Jego powstanie na gruncie europejskim paradoksalnie osłabiało argumentację na rzecz kończenia budowy Galileo.

4 WAAS (Wide Area Augumentation System) — analogiczny do EGNOS system wspomagania różnicowego GPS na terytorium USA. Jest on powszechnie wykorzystywany przez lotnictwo cywilne; SDCM (System for Differential Corrections and Monitoring) - System Różnicowania Korekt i Monitorowania działający na terytorium Federacji Rosyjskiej i dedykowany do wspomagania zarówno GPS, jak i GLONASS; GAGAN (GPS Aided Geo Augumented Navigation) — system wspomagający działanie GPS na terytorium Indii; MSAS (Multi-Functional Satellite Augumentation System) - system wspomagający działanie GPS na terytorium Japonii. Jego następcą jest również oparty na współpracy z GPS system QZSS (Quasi-Zenith Satellite System). Ten ostatni ma być bardziej precyzyjny i znajdować zastosowanie w precyzyjnym rolnictwie, przy dronach, samochodach autonomicznych i pieszych. Ma ułatwiać poruszanie się w tzw. kanionach miejskich, gdzie nie jest możliwy dokładny pomiar za pomocą konstelacji GPS.

5 J.C. Moltz, Asia's Space Race: National Motivations, Regional Rivalries, and International Risks, New York 2012.

${ }^{6}$ J. Ryzenko, Kształtowanie się europejskiej polityki kosmicznej, „Stosunki Międzynarodowe” 2005, nr $1-2$. 
Systemów Nawigacji Satelitarnej oraz Europejskiej Agencji do spraw Globalnych Systemów Nawigacji Satelitarnej. Analizie zostaną także poddane informacje zamieszczane na stronach rządowych agencji zajmujących się zarządzaniem poszczególnymi systemami. Skorzystam ponadto $\mathrm{z}$ treści portali tematycznych dotyczących aktywności w przestrzeni kosmicznej, w tym specjalizujących się w dziedzinie GNSS. Dokonam również zestawienia komunikatów agencyjnych, w tym zwłaszcza przybliżających obraz stosunków rosyjsko-chińskich komunikatów agencji TASS jako uzupełnienia brakujących źródeł. By zachować jasność wywodu, wyjaśnienie terminów technicznych zamieszczę w przypisach.

\section{Systemy globalnej nawigacji satelitarnej — krótka charakterystyka}

\section{GPS-NAVSTAR}

Do powstania amerykańskiego GPS (Global Navigation System) przyczyniła się bezpośrednio zimnowojenna rywalizacja ze Związkiem Radzieckim. Był on początkowo przeznaczony tylko do celów wojskowych i jako taki miał zastąpić przestarzały system Transit pracujący w oparciu o tzw. efekt Dopplera. GPS był budowany w latach 1978-1994. Pełną globalną operacyjność ogłoszono rok później - 17 lipca 1995 r. ${ }^{7}$ Wówczas to, wbrew początkowym zapowiedziom, jeden z sygnałów został udostępniony wszystkim cywilnym użytkownikom. Decyzja w tej sprawie została podjęta jeszcze przez prezydenta Ronalda Reagana w 1983 r. w reakcji na omyłkowe zestrzelenie przez Związek Radziecki u wybrzeży Sachalinu koreańskiego Boeinga 747 z 268 osobami na pokładzie ${ }^{8}$.

W okresie prezydentury Billa Clintona Stany Zjednoczone zaczęły dostrzegać pozamilitarne znaczenie GPS, jako ważnego atutu gospodarczego. Świadczyć o tym mogą założenia amerykańskiej polityki wobec GPS, z których wynikało, iż system ma służyć nie tylko celom militarnym, ale również cywilnym i naukowym. Pod stwierdzeniem tym kryła się chęć wykorzystania GPS w celu podniesienia konkurencyjności gospodarki amerykańskiej na światowym rynku9 . Implementacją tych założeń było zwiększenie konkurencyjności samego systemu poprzez udostępnienie wszystkim odbiorcom bardziej precyzyjnego sygnału ${ }^{10}$. Do maja 2000 r. Stany Zjednoczone celowo bowiem pogarszały

7 J. Januszewski, Systemy satelitarne GPS, Galileo i inne, Warszawa 2007, s. 94.

8 C. Pellerin, United States Updates Global Positioning System Technology. New GPS Satellite Ushers in a Range of Future Improvements, https://web.archive.org/web/20080129150600/http://www.america.gov/ st/washfile-english/2006/February/20060203125928lcnirellep0.5061609.html (dostęp: 20.03.2018).

${ }^{9}$ K. Myszona-Kostrzewa, Nawigacja satelitarna w świetle prawa międzynarodowego, Warszawa 2011, s. 24 .

10 O gospodarczym tle tej decyzji świadczy fakt, iż w swoim oświadczeniu uzasadniającym jej podjęcie prezydent Bill Clinton zachęcał do inwestowania w amerykański GPS i wynajdywania nowych aplikacji cywilnych zarówno komercyjnych, jak i naukowych — zob. Statement by the President Regarding the United States' Decision to Stop Degrading Global Positioning System Accuracy, https://clintonwhitehouse3.archives. gov/WH/EOP/OSTP/html/0053_2.html (dostęp: 10.05.2018). 
precyzję odczytu pozycji odbiorników naziemnych, stosując tzw. Selective Availability (SA). Rodziło to dodatkowe argumenty dla zwolenników budowy europejskiego GNSS ${ }^{11}$.

Do czasu zyskania pełnej operacyjności przez rosyjski system GLONASS w 2015 r. amerykański GPS pozostawał jedynym globalnie działającym i powszechnie dostępnym systemem nawigacji satelitarnej, co zapewniało USA ugruntowaną przewagę militarną, jako posiadaczom tego komponentu obrony narodowej, który - mówiąc dosadnie naprowadza taktyczne rakiety na cel. Ponadto posiadanie systemu GPS gwarantowało USA pozycję lidera wśród dostawców sygnałów do odbiorników GNSS. Tym samym system dedykowany pierwotnie do celów militarnych związanych z wyścigiem zbrojeń stał się poważnym atutem gospodarczym podnoszącym konkurencyjność kilku sektorów gospodarki amerykańskiej. Nie zmienia to jednak faktu, iż - jak zauważa Katarzyna Myszona-Kostrzewa - GPS w dalszym ciągu podlega Departamentowi Obrony USA i nie istnieją żadne prawnomiędzynarodowe zobowiązania Stanów Zjednoczonych uniemożliwiające temu mocarstwu ograniczenie dostępności lub nawet całkowite wyłączenie sygnału ${ }^{12}$. System GPS motywował inne kraje do stworzenia analogicznych systemów precyzyjnego pomiaru pozycji, prędkości i czasu.

\section{GLONASS}

Budowę rosyjskiego GNSS (Globalnaja nawigacionnaja sputnikowaja sistiema) rozpoczęto jeszcze w czasach Związku Radzieckiego, w 1976 r., podobnie jak w przypadku USA głównie z myślą o zastosowaniu wojskowym. Geneza tego systemu była zatem również zimnowojenna. Pełną operacyjność GLONASS zyskał w styczniu 1996 r. Jednak ze względu na wysoką awaryjność poszczególnych satelitów (o wiele większą niż amerykańskie GPS) działał zaledwie kilka miesięcy ${ }^{13}$. Kryzys gospodarczy lat 90. uniemożliwił Rosjanom wynoszenie na orbitę kolejnych sprawnych jednostek, w wyniku czego ich liczba w 2001 r. zmalała do zaledwie sześciu ${ }^{14}$. Dalszą budowę sytemu i przywracanie jego pełnej operacyjności podjęto w okresie rządów prezydenta Władimira Putina i lepszej koniunktury gospodarczej w Rosji. Pomimo znacznych nakładów rzędu 140,1 mld rubli (w latach 2002-2011) pełną operacyjność nad terytorium Federacji Rosyjskiej GLONASS uzyskał dopiero w 2010 r. ${ }^{15} 7$ grudnia 2015 r. ogłoszono pełną globalną operacyjność systemu ${ }^{16}$. W międzyczasie Rosjanie unowocześnili system, wprowadzając nowsze, a zarazem bar-

11 J. Januszewski, op. cit., s. 266. Zwiększenie średniej precyzji lokalizacji z 200-300 m do 4-12 m podważało jeden z głównych europejskich argumentów na rzecz budowy bardziej precyzyjnego Galileo.

12 K. Myszona-Kostrzewa, op. cit., s. 25.

13 J. Januszewski, op. cit., s. 208.

14 F. Verger, I. Sourbés-Verger, R. Ghirardi, The Cambridge Encyclopedia of Space. Missions, Applications and Exploration, Cambridge 2003, s. 323.

15 B. Butrin, I. Konovalov, T. Grishina, GLONASS Hits a SNAG, https://www.rbth.com/articles/2010/12/07/glonass_hits_a_snag05184.html (dostęp: 20.03.2018).

16 Razrabotcziki objawili o zawerszenni cozdania glonass (2015), https://lenta.ru/news/2015/12/07/ glonass/ (dostęp: 12.03.2018). 
dziej żywotne generacje satelitów ${ }^{17}$. W dokumentach uzasadniających budowę systemu w pierwszej kolejności wskazuje się cele gospodarcze i strategiczne, jak uniezależnienie się od amerykańskiego GPS ${ }^{18}$. Może to świadczyć o chęci dokonania analogicznej do GPS postzimnowojennej ewolucji tego programu i rozszerzenia zakresu jego działania na obszar cywilnych zastosowań komercyjnych.

\section{Galileo}

Trzecim w kolejności rozpoczęcia budowy jest europejski system Galileo (nazwa własna). Sama idea budowy europejskiego GNSS pojawiła się jeszcze w połowie lat 80 . XX w. za sprawą francuskiego Narodowego Centrum Badań Kosmicznych (CNES). Strategiczną decyzję o budowie Galileo i zaangażowaniu w ten proces Unii Europejskiej podjęto na posiedzeniu Rady do spraw Transportu 11 kwietnia $2001 \mathrm{r} .{ }^{19}$ Natomiast tworzenie segmentu kosmicznego, czyli rozmieszczanie satelitów, rozpoczęto 28 grudnia $2005 \mathrm{r}^{20}$ Budowa europejskiego GNSS wielokrotnie stawała pod znakiem zapytania zarówno za sprawą czynników zewnętrznych (np. zniesienie przez USA Selective Availability), jak i wewnętrznych, związanych m.in. z kwestią finansowania całego przedsięwzięcia. Początkowo planowano sfinansowanie fazy implementacyjnej (wynoszenia na orbitę) w oparciu o środki prywatne pozyskane dzięki zastosowaniu formuły partnerstwa publiczno-prywatnego. W 2007 r. Komisja Europejska była jednak zmuszona prosić Parlament Europejski o dofinansowanie projektu ze środków publicznych ${ }^{21}$. Koszty i data zakończenia prac Galileo były wielokrotnie zmieniane. System zyskał wstępną operacyjność 15 grudnia 2016 r. ${ }^{22}$ Pełne ukończenie Galileo i uzyskanie globalnej operacyjności planuje się na $2020 \mathrm{r}^{23}$

Ważnym elementem propagandowym mającym mobilizować Europejczyków do ukończenia systemu jest jego cywilny charakter, czym Galileo ma wyraźnie różnić się od jego pozaeuropejskich odpowiedników. Jak wykazuje analiza rezolucji Parlamentu Europejskiego poświęconych problematyce kosmicznej, ma to bezpośredni związek z całą europejską polityką kosmiczną, w której akcentuje się wolę zachowania pozamilitarnej

17 W 2011 r. Federacja Rosyjska wzorem USA rozpoczęła wymianę swoich jednostek orbitalnych GLONASS-M na satelity GLONASS-K o żywotności do 10 lat.

18 Fiederalnaja celewaja programma globalnaja nawigacionnaja sistiema, http://www.gpssoft.ru/ fcp_glonass.html (dostęp: 12.05.2018).

19 I. Słomczyńska, Europejska polityka kosmiczna, Lublin 2017, s. 410.

20 Wówczas to wyniesiony został na orbitę pierwszy testowy satelita Giove A. Jego głównym zadaniem było rozpoczęcie nadawania na częstotliwościach przydzielonych UE przez Międzynarodowy Związek Telekomunikacyjny (ITU).

21 P. Turczyński, European Satellite Navigation System „Galileo”, [w:] European Union as a Global Actor. Political Integration: Identity Issues and Foreign Policy, red. J. Dyduch, M. Michalewska-Pawlak, R. Murphy, Warszawa 2014, s. 237.

22 Galileo Begins Serving, http://www.esa.int/Our_Activities/Navigation/Galileo_begins_serving_ the_globe (dostęp: 20.03.2018).

${ }^{23} \mathrm{FAQ}$, https://www.gsa.europa.eu/european-gnss/galileo/faq\#constellation (dostęp: 21.03.2018). 
specyfiki ${ }^{24}$. Jeszcze na początku XXI w., głównie za sprawą Francji, silnie eksponowano rywalizacyjny charakter Galileo w stosunku do GPS. Motyw ten przybliża nas do właściwej genezy Galileo, jaką była - akcentowana zwłaszcza we francuskich opracowaniach - konieczność strategicznego i gospodarczego uniezależnienia się Europy od USA i amerykańskich technologii satelitarnych ${ }^{25}$. Geneza europejskiego GNSS wyraźnie odróżnia go od systemów amerykańskich i rosyjskich. Wyraźnie brakuje motywów zimnowojennych. Nie oznacza to jednak braku zbieżności w przypadku celów gospodarczych, a także strategicznych. Europa pragnie rywalizować na równi z innymi mocarstwami na rynku dostawców sygnału GNSS, a także opartych na nim usług komercyjnych. Świadczyć o tym może m.in. powołanie do życia Europejskiej Agencji do spraw Globalnych Systemów Nawigacji Satelitarnej.

\section{BeiDou (Compass)}

Chiński system nawigacji satelitarnej BeiDou (w tłum. Wielka Niedźwiedzica) - określany również dla użytku zewnętrznego jako Compass - występuje zasadniczo w dwóch wersjach. Pierwsza, zwana BeiDou-1, była wynoszona na orbitę w latach 2000-2003. $\mathrm{Z}$ założenia miał to być system eksperymentalny o zasięgu regionalnym. Niebagatelny wpływ na decyzję o budowie przez Chiny własnego systemu nawigacji satelitarnej miał incydent z 7 maja 1999 r., kiedy to w trakcie natowskich bombardowań Jugosławii omyłkowo uderzono w gmach chińskiej ambasady w Belgradzie ${ }^{26}$. W sierpniu 2004 r. podjęto decyzję o budowie drugiej wersji - BeiDou-2. Tym razem system ten miał mieć zasięg globalny, jednak Chińczycy przynajmniej do końca 2006 r. nie ujawniali tego faktu ${ }^{27}$. Zapewne na decyzję o budowie nowego systemu wpłynęło rozczarowanie uczestnictwem w finansowaniu budowy europejskiego Galileo, o czym wspomnę jeszcze poniżej. W 2012 r. BeiDou-2 zyskał pełną operacyjność nad terytorium Chin i krajów sąsiednich. Do 2020 planowane jest pokrycie jego zasięgiem całej kuli ziemskiej ${ }^{28}$. Pierwotna geneza

${ }^{24}$ Rezolucja Parlamentu Europejskiego z dnia 8 czerwca 2016 r. w sprawie zdolności polityki bezpieczeństwa i obrony do działania w przestrzeni kosmicznej (2015/2276 (INI)), http://www.europarl.europa.eu/ sides/getDoc.do?pubRef=-//EP//TEXT+TA+P8-TA-2016-0267+0+DOC+XML+V0//PL (dostęp: 12.03.2018); Rezolucja Parlamentu Europejskiego z dnia 12 września 2017 r. w sprawie strategii kosmicznej dla Europy (2016/2325 (INI)), http://www.europarl.europa.eu/sides/getDoc.do?pubRef=-//EP//TEXT+TA+P8-TA-2017-0323+0+DOC+XML+V0//PL (dostęp: 12.03.2018).

25 System Nawigacyjny Galileo. Aspekty strategiczne, naukowe i techniczne, Warszawa 2006, s. 12-13, 16, 98. Szerzej przedstawiłem europejską argumentację na rzecz uniezależnienia się od USA w dziedzinie GNSS w osobnym artykule - zob. B. Smolik, Unia Europejska w obliczu głównych wyzwań polityki kosmicznej, „Wrocławskie Studia Politologiczne” 2008, nr 9, s. 18.

26 Amerykańskie lotnictwo użyło wówczas bomb typu JDAM precyzyjnie naprowadzanych przez GPS, a zatem wykorzystano systemy naprowadzania, których wtedy nie posiadała armia chińska, co uwidoczniło dystans technologiczny dzielący siły zbrojne obydwu mocarstw.

27 L. Chengzhi, The Chinese GNSS-System development and policy analysis, „Space Policy” 29, 2013, nr 1, s. 13,14

${ }^{28}$ BeiDou (Big Dipper / COMPASS), https://www.globalsecurity.org/space/world/china/beidou.htm (dostęp: 13.03.2018). 
powstania systemu BeiDou ma zatem ścisły związek z dążeniem do niwelowania dystansu technologicznego, jaki dzielił amerykańskie i chińskie siły zbrojne. Najwyraźniej jednak z czasem dążenia władz ChRL rozszerzyły się na kwestie ekonomiczne związane $\mathrm{z}$ konkurencyjnością własnej gospodarki ${ }^{29}$.

Niezależne od tego BeiDou odgrywa ważną rolę w regionie Azji Wschodniej i Południowej, gdzie może stać się istotnym atutem militarnym wzmacniającym pozycję Chin względem krajów sąsiednich. Chiny mogą np. udostępniać wysoce precyzyjny kodowany sygnał wojskowy swoim regionalnym sojusznikom skonfliktowanym $\mathrm{z}$ innymi sąsiadami. Taka deklaracja pojawiła się już odnośnie do Pakistanu ${ }^{30}$.

\section{Płaszczyzny rywalizacji i współpracy}

Zagadnienie pokojowego wykorzystania GNSS pojawia się na forum ONZ przynajmniej od 1999 r. ${ }^{31}$ Jak dotąd wspólne uzgodnienia państw członkowskich ONZ ograniczają się do powołania do życia w czasie konferencji ONZ w Wiedniu w dniach 1-2 grudnia 2005 r. Międzynarodowego Komitetu do spraw Globalnych Systemów Nawigacji Satelitarnej $(\mathrm{ICG})^{32}$. Jest to nieformalny organ nieposiadający podmiotowości międzynarodowej, mimo iż jego struktura i funkcjonowanie przypominają budowę i działanie organizacji międzynarodowej ${ }^{33}$. Komitet skupia wybrane państwa członkowskie ONZ, jak również różne instytucje rządowe i organizacje pozarządowe ${ }^{34}$. Należą do niego państwa

29 Hipotezę tę zdaje się potwierdzać niedawna zapowiedź instalacji nowej wersji systemu BeiDou-3. Ten system o zasięgu globalnym pod względem precyzji pomiaru i niezawodności będzie zdolny konkurować z GPS trzeciej generacji, a także bardziej dokładnymi serwisami Galileo. Jego satelity mają charakteryzować się większą żywotnością (do 10 lat lub więcej) niż BeiDou-2 i niezawodnością. System ten będzie zatem bardziej konkurencyjny. Ponadto ma umożliwiać przesyłanie informacji tekstowych typu SMS - Differences between BeiDou-3 and the Previous Two Generations of BeiDou Satellites, http://en.chinabeidou.gov. $\mathrm{cn} / \mathrm{c} / 772 . \mathrm{html}$ (dostęp: 24.05.2018).

30 B. Wang, China Will Make BeiDou Navigation Satellite System Available to Global Users by 2020, https://www.nextbigfuture.com/2016/06/china-will-make-beidou-navigation.html (dostęp: 5.07.2018).

31 Prawdopodobnie pierwszym tego przykładem było wskazanie problemów GNSS w deklaracji wydanej pod koniec III Konferencji ONZ w sprawie badania i pokojowego wykorzystania przestrzeni kosmicznej - zob. The Space Millennium: Vienna Declaration on Space and Human Development, http:// www.unoosa.org/pdf/reports/unispace/viennadeclE.pdf (dostęp: 17.05.2018). W dokumencie wśród wielu globalnych wyzwań wymienia się m.in. wzmocnienie efektywności i bezpieczeństwa transportu, systemów ratownictwa, geodezji i innych aktywności poprzez promowanie powszechnego dostępu i kompatybilności radionawigacji satelitarnej (punkt V).

${ }^{32}$ Komitet działa na podstawie zasad zawartych $\mathrm{w}$ raporcie $\mathrm{z}$ jego pierwszego spotkania $\mathrm{w}$ Wiedniu 1 i 2 listopada 2006 r. - zob. Meeting of the International Committee on Global Navigation Satellite Systems, (Vienna, 1-2 listopada 2006), http://www.unoosa.org/pdf/reports/ac105/AC105_879E.pdf (dostęp: 17.05.2018).

33 K. Myszona-Kostrzewa, op. cit., s. 114.

34 Do Komitetu należą państwa i podmioty posiadające własne zdolności w dziedzinie GNSS lub też właśnie je tworzące albo posiadające programy wdrażania zastosowań nawigacji satelitarnej, czyli Chiny, Unia Europejska, Stany Zjednoczone, Federacja Rosyjska, Włochy, Malezja, Zjednoczone Emiraty Arabskie, Indie, Japonia, Nigeria. Ponadto jako członkowie stowarzyszeni i obserwatorzy do Komitetu należą 
i podmioty posiadające własne zdolności w dziedzinie GNSS, właśnie je tworzące lub posiadające programy wdrażania zastosowań nawigacji satelitarnej, czyli Chiny, Unia Europejska, Stany Zjednoczone, Federacja Rosyjska, Włochy, Malezja, Zjednoczone Emiraty Arabskie, Indie, Japonia, Nigeria. Niezależnie od tego, jako członkowie stowarzyszeni i obserwatorzy, do Komitetu należą liczne organizacje rządowe i pozarządowe powiązane $\mathrm{z}$ sektorem kosmicznym.

Jedną z głównych przyczyn powstania Komitetu była konieczność wypracowania korzystnych dla wszystkich standardów technicznych. Dotyczyło to zwłaszcza dostawców globalnych systemów nawigacji satelitarnej, autonomicznych systemów regionalnych, a także działających regionalnie systemów wspomagających. Jego głównym zadaniem jest zatem zachęcanie do koordynacji działań pomiędzy dostawcami GNSS, w tym zwłaszcza zapewniania większej kompatybilności ${ }^{35} \mathrm{i}$ interoperacyjności ${ }^{36}$ oraz transparentności ${ }^{37}$. Hasło kompatybilności i interoperacyjności stało się zatem głównym punktem wielu konsultacji i umów międzynarodowych podpisywanych przez dostawców GNSS, a także prac czterech grup roboczych działających przy Komitecie ${ }^{38}$. Mimo to - jak wskazuje Glen Gibbson, założyciel i wieloletni wydawca magazynu „GPS World” - płonne okazały się nadzieje na ograniczenie rywalizacji do wolnorynkowej konkurencji w obrębie sektora przemysłu i usług GNSS ${ }^{39}$. Jak zauważa Katarzyna Myszona-Kostrzewa, logiczną konsekwencją rosnącego znaczenia nawigacji satelitarnej w stosunkach międzynarodowych i światowej gospodarce powinno być przyjęcie odnośnej umowy międzynarodowej lub też deklaracji zasad, które mogłyby stanowić punkt wyjścia dalszych prac prawodawczych. W konsekwencji winno dojść do powstania odrębnej organizacji międzynarodowej działającej wzorem Organizacji Międzynarodowej Lotnictwa Cywilnego ${ }^{40}$. Jak na razie nic nie wskazuje jednak na osiągnięcie niezbędnego w tym wypadku konsensusu.

liczne organizacje rządowe i pozarządowe powiązane z sektorem kosmicznym - zob. International Committee on Global Navigation Satellite Systems (ICG): Members, http://www.unoosa.org/oosa/en/ourwork/ $\mathrm{icg} / \mathrm{members.html} \mathrm{(dostęp:} \mathrm{17.05.2018).}$

35 Postulat kompatybilności odnosi się do możliwości korzystania z systemów nawigacji satelitarnej bez zakłóceń wynikających z nakładania się na siebie fal radiowych o podobnych częstotliwościach. Działania takie są zgodne z zaleceniami Międzynarodowego Związku Telekomunikacyjnego. Zupełne uniknięcie nakładania się częstotliwości jest jednak w przypadku GNSS bardzo trudne.

36 Możliwość korzystania przez jeden odbiornik z sygnałów dwóch lub więcej systemów, co znacznie zwiększa precyzję pomiaru. Zalecenia Komisji dotyczą jednak powszechnie dostępnych sygnałów otwartych, a nie kodowanych, przeznaczonych dla służb mundurowych i ratunkowych.

37 Współpraca między dostawcami w dziedzinie przekazywania danych technicznych na temat własnych systemów. Więcej na temat terminologii akceptowanej przez ICG, w tym zwłaszcza Forum Dostawców - zob. International Committee on Global Navigation Satellite Systems, http://www.unoosa.org/oosa/ en/ourwork/icg/icg.html (dostęp: 13.03.2018).

38 Są to: Grupa Robocza - System, Sygnał i Serwis; Grupa Robocza - Zwiększenie Wydajności GNSS, Nowe Usługi i Możliwości; Grupa Robocza — Rozpowszechnianie Informacji i Budowa Potencjału; Grupa Robocza - Ramy Refrencyjne, Timing i Aplikacje.

39 G. Gibbons, GPS, GLONASS, Galileo, Compass: What GNSS Race? What Competiton, http://www. insidegnss.com/node/1389 (dostęp: 13.03.2018).

40 K. Myszona-Kostrzewa, op. cit., s. 108. 


\section{Stany Zjednoczone-Unia Europejska}

Zgodnie z wydaną przez prezydenta Baracka Obamę w 2010 r. dyrektywą o nazwie Narodowa Polityka Kosmiczna Stanów Zjednoczonych USA powinny zachować „przywództwo w zakresie obsługi, świadczenia i użytkowania globalnych systemów nawigacji satelitarnej”. Równocześnie w dokumencie tym wspomina się o konieczności zachowania otwartego i bezpłatnego dostępu do cywilnego sygnału GPS, jako jednego z warunków zachowania tego "przywództwa"41. Sądzę, iż sformułowania te odzwierciedlają politykę Stanów Zjednoczonych, które dążą do zachowania swojej wciąż dominującej pozycji w obszarze GNSS.

Formalnie Amerykanie podkreślają swoją chęć nawiązania bliskiej, bilateralnej współpracy w dziedzinie GNSS z każdym zainteresowanym krajem ${ }^{42}$. Nietrudno jednak zauważyć zróżnicowanie tych relacji. Niewątpliwie najbardziej rozbudowano stosunki z Unią Europejską oraz jej krajami członkowskimi. Jest to jednak wynik wcześniejszych dysfunkcji we wzajemnych relacjach dotyczących GNSS. Początkowo Stany Zjednoczone najwyraźniej nie chciały zrezygnować ze swojej uprzywilejowanej pozycji jedynego dostawcy globalnego sygnału nawigacji satelitarnej. Już w 2001 r. odwoływano się zatem do argumentów dotyczących bezpieczeństwa, w tym zwłaszcza możliwości zakłócenia ich kodowanego sygnału wojskowego (M-code $)^{43}$. Ze strony Europy - niezależnie od bogatej argumentacji o charakterze ekonomicznym - uzasadniano natomiast konieczność budowy własnego cywilnego systemu, niezależnego od z gruntu militarnego GPS. W wyniku tej specyfiki GPS europejscy odbiorcy jego sygnału mogliby zostać odcięci od newralgicznych usług w przypadku kryzysu lub konfliktu zbrojnego prowadzonego przez USA ${ }^{44}$.

Rozbieżności na tle kwestii związanych z bezpieczeństwem w obrębie krajów NATO skłaniały do rozmów i wstępnych porozumień ${ }^{45}$. Konsensus udało się osiągnąć 26 czerwca 2004 r. w Dromoland Castle w Irlandii w czasie szczytu europejsko-amerykańskiego, kiedy to podpisano porozumienie w sprawie współdziałania GPS i Galileo. Zakładało ono podjęcie współpracy w dziedzinie cywilnych aplikacji GPS i Galileo, a także kompatybilności częstotliwości radiowych. Ustanowiono także cztery spotykające się cy-

41 National Space Policy of United States, 28 czerwca 2010, s. 5, https://www.gps.gov/policy/docs/2010/ (dostęp: 14.03.2018).

42 International Cooperation, https://www.gps.gov/policy/cooperation/ (dostęp: 13.03.2018).

${ }^{43}$ Przykładem tego typu działań może być nieformalny list, jaki 1 grudnia 2001 r. zastępca sekretarza obrony USA Paul Wolfowitz skierował do 15 ministrów obrony narodowej krajów UE, w którym przestrzegał przed ryzykiem takich zakłóceń. Chodziło tu zwłaszcza o sygnał kodowany PRS (Public Regulated Service). Wolfowitz argumentował, iż Amerykanie zamierzają upowszechnić użycie tego sygnału przy wielu operacjach wojskowych. Strona amerykańska dostrzegała także niebezpieczeństwo nieuprawnionego używania PRS przez organizacje terrorystyczne - US Warns against European Satellite System, http:// news.bbc.co.uk/2/hi/europe/1718125.stm (dostęp: 18.05.2018).

44 T. Valasek, Galileo's strategic' Role, [w:] C. Bildt et al., Europe in Space, London 2004, s. 35; G. Lindström, G. Gasparini, The Galileo satellite system and its security implications, „Occasional Paper. Institute for Security Studies" kwiecień 2003, nr 44, s. 5, 21.

${ }^{45}$ M. Polkowska, Prawo kosmiczne w obliczu nowych problemów współczesności, Warszawa 2009, s. 184. 
klicznie grupy robocze, których zadaniem miała być likwidacja wszelkich sprzeczności o charakterze technicznym i komercyjnym ${ }^{46}$. Jest to najszersze jak dotąd porozumienie dwustronne dostawców GNSS ${ }^{47}$. Obie strony dostosowywały się w ten sposób do zobowiązań podjętych w ramach Światowej Organizacji Handlu odnośnie do liberalizacji handlu dobrami i usługami oraz znoszenia wszelkich protekcjonistycznych barier.

W konsekwencji porozumienia z Dromoland Castle prace rozpoczęli eksperci obu stron. W marcu 2006 r. ogłoszono opracowanie wspólnego, zoptymalizowanego sygnału spełniającego wszystkie wymagania kompatybilności i interoperacyjności ${ }^{48}$. Następstwem tego było podjęcie w 2007 r. działań przez wspólne grupy robocze mających na celu wyeliminowanie wzajemnej dyskryminacji oraz zachęcanie przemysłów obu stron do produkcji odbiorników dwusystemowych umożliwiających zwiększenie precyzji lokalizacji i pomiaru ${ }^{49}$. W lipcu 2010 r. ogłoszono także wyniki badań dotyczące poprawy jakości pomiaru w przypadku zastosowania odbiorników dwusystemowych odbierających sygnały z konstelacji satelitów obydwu systemów. Uzgodniono także zasady interoperacyjności odbiorników WAAS i EGNOS, a zatem systemów de facto pochodnych od GNSS, wzmacniających precyzję samego GPS, wykorzystywanych najczęściej przez lotnictwo ${ }^{50}$.

Wciąż powoływane są także nowe podgrupy robocze odnoszące się do bardzo szczegółowych zagadnień technicznych. Jedna z nich, powstała w lutym 2016 r., ma opracować koncepcję zastosowania usługi Advanced RAIM (ARAIM), czyli - ujmując rzecz w skrócie - systemu monitorującego jakość pomiarów GPS i eliminującego zafałszowane odczyty. Znajduje on szerokie zastosowanie w lotnictwie ${ }^{51}$. Reasumując, współpracę amerykańsko-unijną w dziedzinie wykorzystania cywilnych sygnałów GNSS można określić jako dobrą. Bliskie współdziałanie w dziedzinie kompatybilności i interoperacyjności

46 Zgodnie z art. 5 niniejszej umowy obie strony uzgodniły, że „będą się z sobą konsultować przed ustanowieniem norm projektowych lub funkcjonalnych precyzujących wymogi certyfikacyjne, licencyjne, przepisy techniczne lub podobne wymogi mające zastosowanie do cywilnych satelitarnych sygnałów nawigacyjnych i synchronizacji czasu" - Agreement on the Promotion, Provision and Use of Galileo and GPS Satellite-Based Navigation System, Dromoland Castle 2004.

47 A. Arena, I. Baumann, GNSS and World Trade Law: Playing by the Rules, http://insidegnss.com/ auto/julyaug15-BAUMANN.pdf (dostęp: 14.03.2018).

48 Joint Statement on Galileo and GPS Signal Optimization by the European Commission (EC) and the United States (US), https://www.gps.gov/policy/cooperation/europe/2006/joint-statement/ (dostęp: 14.03.2018).

49 Joint Statement United States-European Union GPS-Galileo Working Group "B" on Trade \& Civil Applications U.S. Department of Commerce (2007), Washington, https://www.gps.gov/policy/cooperation/ europe/2007/working-group-b/ (dostęp: 14.03.2018).

50 Joint Statement U.S. and EU Announce Improved Performance from Receivers Using both GPS and Galileo Combined Performance, https://www.gps.gov/policy/cooperation/europe/2010/working-group-c/ (dostęp: 14.03.2018); EU-US Cooperation on Satellite Navigation, Working Group C, Combined Performances for SBAS Receivers using WAAS and EGNOS, Final version, 19 lipca 2010, https://www.gps.gov/policy/ cooperation/europe/2010/working-group-c/combined-WAAS-EGNOS.pdf (dostęp: 21.05.2018); EU-US Cooperation on Satellite Navigation, Working Group C, Combined Performances for Open GPS/GALILEO receivers, Final version, 19 lipca 2010, https://www.gps.gov/policy/cooperation/europe/2010/working-groupc/combined-open-GPS-Galileo.pdf (dostęp: 21.05.2018).

51 ARAIM, http://www.navipedia.net/index.php/ARAIM (dostęp: 14.03.2018). 
najwyraźniej jest korzystne dla obu stron. Nie wyklucza ono jednak rywalizacji w dziedzinie ekonomicznej. Na podkreślenie zasługuje jednak fakt dobrowolnego pozostawienia - wbrew intencjom Francji - dotychczasowego uzależnienia wojskowej infrastruktury europejskich państw NATO od wojskowego sygnału GPS ${ }^{52}$. W tym wypadku nałożyły się na siebie dążenia do monopolizacji tej sfery przez USA w obrębie NATO i europejska niechęć do militaryzacji przestrzeni kosmicznej.

\section{Stany Zjednoczone-Federacja Rosyjska}

O wiele słabiej rozwija się natomiast współpraca pomiędzy Stanami Zjednoczonymi a Federacją Rosyjską. W wyniku dwudniowych rozmów w Waszyngtonie w grudniu 2004 r. obie strony wystosowały wspólne oświadczenie, w którym zobowiązały się do współpracy mającej na celu doprowadzenie do kompatybilności i interoperacyjności obydwu systemów. W tym celu powołano wspólne grupy robocze ${ }^{53}$. Jak wynika z dalszych dokumentów, przystąpiły one do pracy, jednak postęp był bardzo powolny ${ }^{54}$. Głównym przedmiotem sporów nie były kwestie związane z komercyjnym i naukowym wykorzystaniem GNSS, lecz z rozdziałem częstotliwości przeznaczonych dla wojska. Jak wynika z dokumentów ujawnionych przez Departament Obrony USA, obie strony nie podpisały jak dotąd żadnego znaczącego porozumienia.

W 2014 r. w ustawie dotyczącej finansowania sił zbrojnych USA (National Defense Authorization Act) znalazły się zapisy umożliwiające ograniczenie obecności na terytorium Stanów Zjednoczonych stacji monitorujących obce satelity, stanowiących infrastrukturę systemów GNSS innych krajów w przypadku, gdyby mogły one służyć celom szpiegowskim lub „wzmacnianiu obcego systemu uzbrojenia” ${ }^{5}$. W praktyce USA uznawały w ten sposób za niepożądaną obecność stacji monitorujących satelity GLONASS ${ }^{56}$. Ustawa umożliwiała nadawanie przez obce stacje monitorujące tylko niekodowanych, a zatem mniej precyzyjnych sygnałów. Amerykanie nie kryli jednak, iż poza względami bez-

52 W przytaczanym już powyżej opracowaniu autorstwa pracowników francuskiej Akademii Morskiej, Biura Długości oraz Akademii Lotnictwa i Kosmosu, wydanym pierwotnie w 2003 r., czytamy: „USA może natychmiast unieruchomić systemy uzbrojenia wyposażone w odbiorniki GPS, należące do uczestniczących w niej [operacji wojskowej - B.S.] krajów europejskich” — System Nawigacyjny Galileo..., s. 98.

53 Joint Statement on the U.S. Global Positoning System (GPS) and the Russian Global Navigation Satellite System (GLONASS), https://www.gps.gov/policy/cooperation/russia/2004-joint-statement/ (dostęp: 14.03.2018).

${ }^{54} \mathrm{~W}$ grudniu 2006, po trzech spotkaniach, pierwsza z grup do spraw kompatybilności odnotowała niewielki postęp $\mathrm{w}$ sprawie stosowania pasm kodowanych przeznaczonych dla wojska FDMA i CDMA - United States-Russian Federation. GPS/GLONASS Interoperability and Compatibility Working Group (WG-1). Joint Statement, https://www.gps.gov/policy/cooperation/russia/2006-working-group-1/ (dostęp: 14.03.2018).

55 National Defense Authorization Act for Fiscal Year 2014, s. 273, https://www.gpo.gov/fdsys/pkg/ PLAW-113publ66/pdf/PLAW-113publ66.pdf\#page=273 (dostęp: 19.05.2018).

56 Rosjanie już od 2012 r. ubiegali się o zezwolenie na instalację na terytorium USA swoich stacji monitorujących położenie własnych satelitów. 
pieczeństwa kluczową rolę odgrywają przyczyny ekonomiczne związane z możliwością obniżenia konkurencyjności własnego GPS ${ }^{57}$.

W odpowiedzi Rosjanie w czerwcu tego samego roku ograniczyli dostępność danych napływających ze stacji monitorujących GPS, które znajdują się na terytorium Federacji Rosyjskiej ${ }^{58}$. Wydarzeniu temu nadano charakter propagandowy, toteż stało się ono przedmiotem kontrowersyjnych doniesień medialnych ${ }^{59}$. Zdaniem bardziej obiektywnych w tej sprawie brytyjskich ekspertów, w tym profesora Davida Lasta - byłego dyrektora Królewskiego Instytutu Nawigacji, restrykcje rosyjskie nie pogarszały jakości działania amerykańskiej nawigacji satelitarnej wśród użytkowników na świecie, jednak miały wpływ na lokalnych użytkowników w samej Rosji ${ }^{60}$. Spadła zatem konkurencyjność GPS wobec GLONASS na terytorium Federacji Rosyjskiej. Niebawem rosyjskie stacje śledzące, wchodzące w skład infrastruktury naziemnej GLONASS, zaczęto rozmieszczać - ku zaniepokojeniu USA - na terytorium zaprzyjaźnionych krajów Ameryki Łacińskiej, w tym Nikaragui, która leży stosunkowo blisko Stanów Zjednoczonych ${ }^{61}$. W ten sposób problem związany z rozmieszczeniem elementów segmentu naziemnego obydwu systemów stał się nie tylko elementem rywalizacji gospodarczej, ale również przyczynkiem do odnowienia parazimnowojennej rywalizacji o wpływy w krajach latynoamerykańskich ${ }^{62}$.

Na konfliktogenność relacji amerykańsko-rosyjskich w dziedzinie GNSS wpływa fakt kumulacji rywalizacji militarnej — widocznej w przypadku trudności związanych z uzyskaniem porozumienia $\mathrm{w}$ sprawie wojskowych sygnałów kodowanych $-\mathrm{z}$ rywalizacją gospodarczą. Ta druga odgrywa jednak o wiele mniejszą rolę. Konfrontacyjna polityka dwustronna USA i Federacji Rosyjskiej może mieć duży wpływ na relacje w ramach Międzynarodowego Komitetu do spraw GNSS i utrudniać dalszą współpracę.

\section{Stany Zjednoczone-Chińska Republika Ludowa}

W przypadku relacji amerykańsko-chińskich współpraca w dziedzinie GNSS ogranicza się do prac w dziedzinie kompatybilności, a także interoperacyjności w kontekście

57 H. Bartkowiak, GLONASS bez stacji śledzenia w USA, http://kosmonauta.net/2014/01/glonass-bez-stacji-sledzenia-w-usa/ (dostęp: 15.03.2018).

58 Russia Turns IGS Data Back on - Sort of, http://gpsworld.com/russia-turns-igs-data-back-on-sortof/ (dostęp: 15.03.2018).

59 Wbrew niektórym mediom i oświadczeniu wicepremiera Rosji Dmitrija Rogozina Rosjanie nie wyłączali nieistniejących amerykańskich stacji monitorujących, lecz ograniczali działanie swoich własnych należących do infrastruktury International GNSS Service, czyli międzynarodowej służby cywilnej służącej celom naukowym - M. Gruszczyński, Jak wyłączyć GPS?, http://kosmonauta.net/2018/03/jak-wylaczyc-gps/ (dostęp: 4.04.2018).

60 J. Miller, Russia to 'Restrict' US-Run GPS Satellites, http://www.bbc.com/news/technology-27662580 (dostęp: 15.03.2018).

${ }^{61}$ F. Ghitis, A Russian Satellite-Tracking Facility in Nicaragua Raises Echoes of the Cold War, https:// www.worldpoliticsreview.com/articles/22385/a-russian-satellite-tracking-facility-in-nicaragua-raisesechoes-of-the-cold-war (dostęp: 15.03.2018).

62 Inne stacje monitorujące położenie rosyjskich satelitów mają być rozmieszczone na Kubie, w Ekwadorze, Meksyku i Argentynie. Rosjanie mają już ponadto cztery analogiczne stacje w Brazylii. 
sygnału cywilnego. Obie strony podkreślają zarazem, iż realizują w ten sposób odnośne zalecenia Międzynarodowego Komitetu do spraw GNSS oraz takich organizacji, jak przede wszystkim Międzynarodowy Związek Telekomunikacyjny (ITU), a także Organizacja Międzynarodowego Lotnictwa Cywilnego (ICAO) i Międzynarodowa Organizacja Morska (IMO) ${ }^{63}$. W grudniu 2017 r., po przeszło trzyletnich rozmowach, ogłoszono osiągnięcie kompatybilności i interoperacyjności obu systemów ${ }^{64}$. Zatem współpraca nie wyszła poza zalecenia organizacji międzynarodowych, ma ona jednak charakter zdecydowanie mniej konfrontacyjny niż w przypadku relacji USA-Federacja Rosyjska. Między obiema stronami nie doszło jak dotąd do żadnych otwartych konfliktów. Niezależnie od tego strona chińska może się czuć usatysfakcjonowana z tytułu pomniejszania dystansu technologicznego istniejącego pomiędzy ChRL a USA. Tworzenie własnego GNSS wpisuje się w długofalową politykę Chin zmierzającą od ograniczania przewagi technologicznej USA. Strona chińska najwyraźniej wykazuje jednak sporo ostrożności. Mając na uwadze całokształt stosunków z USA i wciąż niekwestionowaną pozycję Stanów Zjednoczonych jako lidera w obszarze GNSS, w relacjach z tym supermocarstwem Chińczycy starają się jak na razie unikać sytuacji konfliktogennych.

\section{Federacja Rosyjska-Unia Europejska}

W przypadku drugiego z działających już globalnie systemów nawigacyjnych współpraca $\mathrm{z}$ Unią Europejską w dziedzinie kompatybilności i interoperacyjności formalnie nie napotyka większych przeszkód. Tym niemniej pomimo zapowiedzi nie została poparta osobnymi traktatami, a jedynie ogólnym porozumieniem z 10 marca 2006 r. o wszechstronnym wzmocnieniu współpracy w dziedzinie przestrzeni kosmicznej ${ }^{65}$.

Współpraca europejsko-rosyjska w dziedzinie GNSS wpisuje się bowiem w znacznie szerszy obszar kooperacji w zakresie przestrzeni kosmicznej, która została zapoczątkowana jeszcze w latach 90., kiedy ze strony Europy uczestniczyły w niej głównie Francja i Europejska Agencja Kosmiczna. Zarówno stronę europejską, jak i Rosję skłaniały do niej głównie względy natury ekonomicznej, czyli obniżanie kosztów aktywności kosmicznej i ratowanie miejsc pracy we własnych przemysłach kosmicznych, a także konieczność ich modernizacji. W ramach współpracy obie strony uczestniczyły w programach dotyczących m.in. Międzynarodowej Stacji Kosmicznej (szkolenie i dostarczanie astronautów na orbitę), wspólnego wykorzystywania rakiet Sojuz, wysyłania międzyplanetarnych misji badawczych (np. Exo Mars) ${ }^{66}$.

63 Joint Statement U.S.-China Civil Global Navigation Satellite Systems (GNSS) Cooperation, Beijing 2014, https://www.gps.gov/policy/cooperation/china/2014-joint-statement/ (dostęp: 15.03.2018).

64 Joint Statement on Civil Signal Compatibility and Interoperability between the Global Positioning System (GPS) and BeiDou Navigation Satellite System (BDS), https://www.gps.gov/policy/cooperation/ china/2017-joint-statement/ (dostęp: 15.03.2018).

65 EU and Russia Join Forces and Sign Cooperation Agreement, http://europa.eu/rapid/press-release_IP06-297_en.htm (dostęp: 15.03.2018).

66 E. Avrillon, European-Russian space cooperation in 2030: From commercial partnerships to common exploration programmes?, „European Space Institute Report” styczeń 2013, nr 65, https://espas.secure. 
Federacja Rosyjska do niedawna odgrywała znaczącą rolę na polu świadczenia Europie (mówiąc konkretniej - Europejskiej Agencji Kosmicznej i jej krajom członkowskim) usług wynoszenia na orbity różnych satelitów, w tym również wchodzących w skład konstelacji Galileo. Jednak od września 2014 r., kiedy to dwa z nich zostały umieszczone na niewłaściwej orbicie, Europejczycy dążą do realizacji tego zadania własnymi środkami, przy pomocy rakiet Ariane $6^{67}$.

Reasumując, pomimo zachęcających początków i szerokich oczekiwań rosyjsko-europejska współpraca w dziedzinie GNSS została ograniczona i nie wychodzi poza powszechnie przyjęte zalecenia ICG. Niemniej jednak w przypadku Unii Europejskiej i Federacji Rosyjskiej nie ujawniły się jak dotąd sprzeczności na tle sygnału kodowanego. Nie bez znaczenia jest fakt kompatybilności systemu EGNOS zarówno z amerykańskim GPS, jak i rosyjskim GLONASS.

\section{Federacja Rosyjska-Chińska Republika Ludowa}

Federacja Rosyjska od kilku lat rozwija natomiast ożywioną współpracę z Chińską Republiką Ludową. 13 października 2014 r., w czasie 19. Regularnego Spotkania Szefów Rządów Rosji i Chin, szefowie agencji kosmicznych obu krajów podpisali memorandum dotyczące współpracy w obszarze GSNN ${ }^{68}$. Memorandum zapoczątkowywało rozwijanie szerszej kooperacji w tej stosunkowo wąskiej sferze aktywności, w której to oba państwa pozostają daleko w tyle za USA. W listopadzie tego samego roku zainicjowano powstanie wspólnego centrum wdrażania technologii nawigacji satelitarnej działające na zasadzie joint venture. Obie strony nie ukrywały przy tym, iż jest to przedsięwzięcie obliczone na wspólne pozyskanie rynków Azji Środkowej i Południowej, a także wszystkich krajów członkowskich Wspólnoty Niepodległych Państw ${ }^{69}$. Uzgodniono również wzajemną lokalizację na terytorium obu krajów stacji monitorujących swoje satelity GNSS $^{70} .8$ maja 2015 r. na Kremlu, w trakcie spotkania na szczycie, podpisano wspólne oświadczenie o współdziałaniu obu systemów. Zapowiedziano także prace nad powsta-

europarl.europa.eu/orbis/sites/default/files/generated/document/en/ESPI_Perspectives_65.pdf (dostęp: 18.06.2018).

67 Galileo Satellites Go into Wrong Orbit, European Space Agency Says, https://astronaut.com/galileosatellites-go-wrong-orbit-european-space-agency-says/ (dostęp: 15.03.2018); A. Sitruk, P. Serge, The governance of Galileo, „European Space Institute Report” styczeń 2017, nr 62, https:/espi.or.at/publications/ espi-public-reports (dostęp: 15.03.2018). Istotną rolę odegrały podejrzenia kierowane nieoficjalnie pod adresem Roskosmosu, iż wyniesienie obu jednostek na złe orbity miało związek z sankcjami nałożonymi na Rosję po aneksji Krymu.

68 The Way Forward: 10 Years of Achievement 2005-2015, International Committee on Global Navigation Satellite Systems, http://www.unoosa.org/res/oosadoc/data/documents/2016/stspace/stspace67_0_html/ st_space_67E.pdf (dostęp: 15.03.2018).

69 China to Set Up Joint Venture to Promote Satellite Navigation Services, http://tass.com/nonpolitical/759729 (dostęp: 16.03.2018).

70 Russia to Place GLONASS Monitoring Stations in China, http://tass.com/non-political/759171 (dostęp: 16.03.2018). 
niem odbiorników dwusystemowych ${ }^{71}$. Rok później oba kraje podpisały porozumienie o kompatybilności i interoperacyjności swoich systemów ${ }^{72}$. W lipcu 2017 r. rozpoczęto testowanie współdziałania obu systemów w ramach eksperymentu „Jedwabny Szlak”, wzdłuż międzynarodowej magistrali łączącej Moskwę, Ufę i Nowosybirsk ${ }^{73}$. Zestawienie tych faktów świadczy o żywo rozwijającej się współpracy obu mocarstw, w której jedna strona ma do zaoferowania niebagatelne doświadczenie w dziedzinie aktywności kosmicznej, druga natomiast nieograniczoną ilość środków finansowych.

Należy również zauważyć, iż istnieje, zapewne nieprzypadkowa, zbieżność w czasie pomiędzy procesem zacieśniania rosyjsko-chińskiej współpracy w kosmosie, w tym zwłaszcza w dziedzinie GNSS, a widocznym od kilku lat pogorszeniem się relacji Federacji Rosyjskiej z USA i UE. Koresponduje z tym zainicjowany w 2013 r. gigantyczny chiński projekt inwestycyjny „Jeden Pas i Jedna Droga” (OBOR), który ma na celu wprowadzenie w życie współczesnej, globalnej wersji chińskiego jedwabnego szlaku. Niezależnie od tego oba mocarstwa już od dłuższego czasu dążą do kooperacji w ramach Szanghajskiej Organizacji Współpracy. Nie wyklucza ona jednak możliwości równoległej rywalizacji pomiędzy nimi ${ }^{74}$. Jak na razie trudno ją jednak dostrzec w obszarze GNSS, w którym to oba mocarstwa próbują nadrobić dystans dzielący je od Stanów Zjednoczonych.

\section{Unia Europejska-Chińska Republika Ludowa}

Niezwykle interesująco przedstawiają się relacje europejsko-chińskie w dziedzinie GNSS, gdyż Galileo i BeiDou mają zyskać swoją pełną operacyjność w 2020 r. Początkowo Chiny gotowe były partycypować w budowie europejskiego GNSS ${ }^{75}$. Na mocy umowy z 9 października 2004 r. zobowiązały się do wkładu finansowego wysokości $200 \mathrm{mln}$ euro. Fakt, iż strona chińska została dopuszczona do Wspólnego Przedsiębiorstwa Galileo (Galileo Joint Undertaking), wynikał zarówno z chęci pozyskania zewnętrznych środków, jak i słabej orientacji urzędników Komisji Europejskiej na temat oczekiwań Chińczyków wobec Galileo ${ }^{76}$.Zaistniała groźba przejęcia przez stronę chińską technologii do własnych celów wojskowych ${ }^{77}$. Ze strony Europy pojawiły się opory co do udostępnienia Chinom

${ }^{71}$ China Agree on Joint Use of GLONASS, BeiDou Navigation Systems, http://tass.com/non-political/793687 (dostęp: 17.03.2018).

72 Differential for GLONASS-BeiDou, http://www.rin.org.uk/NewsItem/4832/Differential-forGLONASS-BeiDou (dostęp: 17.03.2018).

73 Russia-China Project Committee on Important Strategic Cooperation in Satellite Navigation, https:// www.glonass-iac.ru/en/AboutIAC/silkroad2017.php (dostęp: 18.03.2018).

74 A. Kobierecka, Szanghajska Organizacja Współpracy jako jedna z form wielopłaszczyznowej współpracy Rosji i Chińskiej Republiki Ludowej, „Athenaeum. Polskie Studia Politologiczne” 54, 2017, nr 2, s. 54.

75 Strona chińska zadeklarowała wówczas bliżej nieokreślony wkład finansowy oraz chęć uczestnictwa we Wspólnym Przedsiębiorstwie Galileo - zob. Cooperation Agreement on a Civil Global Navigation Satellite System (GNSS) - GALILEO between the European Community and Its Member States and the People's Republic of China, Beijing, 30 października 2003, http://ec.europa.eu/world/agreements/prepareCreateTreatiesWorkspace/treatiesGeneralData.do?step=0\&redirect=true\&treatyId=9226 (dostęp: 19.05.2010).

76 I. Słomczyńska, op. cit., s. 423, 425.

77 L. Chengzhi, op. cit., s. 14; P. Turczyński, op. cit., s. 235. 
kodowanego i wysoce precyzyjnego sygnału PRS ${ }^{78}$, który mógłby mieć również zastosowanie wojskowe i nieoficjalnie miał być zarezerwowany tylko dla rządów europejskich ${ }^{79}$. Z czasem, po wycofaniu się strony chińskiej z europejskiego GNSS, pojawił się problem nakładania się częstotliwości używanych przez BeiDou i sygnał kodowany Galileo (PRS). Rozmowy w tej sprawie trwały bez powodzenia przez kilka lat ${ }^{80}$.

Problem pełnej kompatybilności BeiDou z Galileo (łącznie z serwisami kodowany$\mathrm{mi})$ przez długi czas pozostawał kwestią otwartą ${ }^{81}$. Jak na razie brakuje jednoznacznych informacji o jego rozwiązaniu ${ }^{82}$. Zapewne nieprzypadkowo strona chińska hamuje finalizację rozmów z dysponentem systemu, który ma rozpocząć swoje działanie w 2020 r., a zatem w tym samym czasie, kiedy to pełną globalną operacyjność zyska również system BeiDou. Europa i Chiny przeszły więc ewolucję w swych stosunkach od nieudanych prób kooperacji przy budowie jednego globalnego systemu do rywalizacji o pozycje startowe dla budowanych przez siebie osobnych systemów globalnej nawigacji satelitarnej. Rywalizacja ta nie ma jednak charakteru militarnego, lecz przede wszystkim gospodarczy.

\section{Podsumowanie}

Odpowiadając na pytanie postawione na wstępie tego artykuł, należy wysunąć kilka bardziej szczegółowych wniosków dotyczących relacji pomiędzy poszczególnymi obecnymi lub przyszłymi dostawcami GNSS.

1. W dziedzinie relacji amerykańsko-europejskich widoczne jest odchodzenie od rywalizacji w dziedzinie politycznej, a także militarnej, w tym zwłaszcza handlu bronią. Unia Europejska niejako sama wykluczyła tę drugą, odżegnując się od chęci wykorzystywania Galileo do celów obronnych i tym samym godząc się na uzależnienie od wojskowych częstotliwości GPS. Pozostawiono jedynie możliwość rywalizacji gospodarczej. Po fiasku Strategii Lizbońskiej z 2000 r. i pojawieniu się nowych konkurentów jest ona jednak słabiej akcentowana przez stronę europejską.

78 PRS (Public Regulated Service) — kodowany sygnał Galileo przeznaczony dla służb mundurowych i ratownictwa. Charakteryzuje go wysoka odporność na celowe i przypadkowe zagłuszenia (jamming) i zafałszowania (spoofing), a także gwarancja ciągłości nadawania w momentach kryzysowych.

79 P. de Selding, Galileo Faces More Delays, New Challenges from China, http://spacenews.com/galileofaces-more-delays-new-challenges-china/ (dostęp: 31.03.2018).

80 Idem, Europe, China at Impasse on Satellite Navigation Overlap, http://spacenews.com/europe-chinaimpasse-satellite-navigation/ (dostęp: 31.03.2018).

81 The Way Forward..., s. 41.

82 Strona chińska informuje, iż rozmowy w tej sprawie zostały zakończone, a mechanizm współpracy między systemami ,jest przedmiotem dyskusji, zwłaszcza w dziedzinie interoperacyjności i kompatybilności" - Development of BeiDou Navigation Satellite System (BDS) - A System Update Report (2017-2018), Dr Jun Shen Deputy Director International Cooperation Centre China Satellite Navigation Office (CSNO), https://www.gps.gov/cgsic/meetings/2017/shen.pdf (dostęp: 23.05.2018). Również ostatnia coroczna konferencja w Monachium (5-7 marca 2018 r.) nie przyniosła w tej sprawie żadnych konkretnych informacji. 
2. Widoczna jest postępująca rywalizacja pomiędzy Stanami Zjednoczonymi i Federacją Rosyjską w dziedzinie militarnej i ekonomicznej. Proces ten został znacznie przyspieszony po aneksji Krymu przez Rosję. Ta ostatnia próbuje również zmniejszyć przewagę USA w dziedzinie gospodarczej, stosując przepisy nakazujące używanie systemu GLONASS w samochodach i urządzeniach funkcjonujących na własnym terytorium. Zdecydowanie mniej konfrontacyjne w dziedzinie GNSS wydają się stosunki chińsko-amerykańskie.

3. W relacjach chińsko-rosyjskich widoczna staje się przede wszystkim współpraca zmierzająca do wspólnego opanowania rynku azjatyckiego. W prognozach na rok 2025 obszar Azji i Pacyfiku ma się stać najpotężniejszym rynkiem profesjonalnych usług GNSS na świecie ${ }^{83}$. Nie wyklucza to jednak cichej rywalizacji w przyszłości, nawet w ramach Szanghajskiej Organizacji Współpracy czy innych organizacji zrzeszających państwa azjatyckie.

4. Równocześnie zarysowuje się coraz ostrzejsza rywalizacja europejsko-chińska. Obie strony planują bowiem uzyskanie pełnej globalnej operacyjności swoich systemów w tym samym roku. Od kilku lat dostrzegalny jest zatem pośpiech przy finalizacji budowy konstelacji satelitów. Rywalizacja Unii Europejskiej z Chinami nie ma jednak charakteru politycznego ani militarnego, dotyczy natomiast miejsca na rynku usług GNSS i możliwości podpisania bardziej intratnych kontraktów.

Reasumując - w dziedzinie globalnej nawigacji satelitarnej obecna jest zarówno rywalizacja, jak i współpraca, które postrzegane wielopłaszczyznowo nie muszą się wzajemnie wykluczać. Współpraca wynika zazwyczaj z racjonalnej kalkulacji ekonomicznej. Rywalizacja może łączyć się ze względami natury gospodarczej i strategicznej czy wręcz militarnej. Militaryzacja kosmosu stanowi zatem sama w sobie element silnie konfliktogenny, czego potwierdzeniem mogą być relacje w dziedzinie GNSS ${ }^{84}$. Szczególnie wiele nieporozumień rodzi problem kompatybilności sygnałów kodowanych związanych z obronnością i bezpieczeństwem danego kraju, w tym również możliwością ich wykorzystywania przez grupy dyspozycyjne. Niezależnie od tego pojawiają się stare zimnowojenne resentymenty widoczne w relacjach amerykańsko-rosyjskich.

\section{Bibliografia}

Agreement on the Promotion, Provision and Use of Galileo and GPS Satellite-Based Navigation System, Dromoland Castle 2004.

ARAIM, http://www.navipedia.net/index.php/ARAIM (dostęp: 14.03.2018).

${ }^{83}$ GNSS Market Report, European Global Navigation Satellite System Agency, 2017, nr 5, https://www. gsa.europa.eu/system/files/reports/gnss_mr_2017.pdf (dostęp: 1.04.2018), s. 6.

84 Terminem militaryzacji kosmosu określa się militarne zastosowanie przestrzeni kosmicznej (satelity szpiegowskie, GNSS, programy Space Surveillance and Tracking i inne) różne od weaponizacji kosmosu, czyli rozmieszczania na orbicie broni służącej bezpośrednio do rażenia celów w kosmosie i na Ziemi — zob. I. Słomczyńska, op. cit. s. 145; K. Myszona-Kostrzewa, op. cit., s. 210. 
Arena A., Baumann I., GNSS and World Trade Law: Playing by the Rules, http://insidegnss.com/auto/ julyaug15-BAUMANN.pdf (dostęp: 14.03.2018).

Avrillon E., European-Russian space cooperation in 2030: From commercial partnerships to common exploration programmes?, „European Space Institute Report” styczeń 2013, nr 65, https://espas.secure.europarl.europa.eu/orbis/sites/default/files/generated/document/en/ESPI_Perspectives_65.pdf (dostęp: 18.06.2018).

Bartkowiak H., GLONASS bez stacji śledzenia w USA, http://kosmonauta.net/2014/01/glonass-bez-stacji-sledzenia-w-usa/ (dostęp: 15.03.2018).

BeiDou (Big Dipper/COMPASS), https://www.globalsecurity.org/space/world/china/beidou.htm (dostęp: 13.03.2018).

Butrin B., Konovalov I., Grishina T., GLONASS Hits a SNAG, https://www.rbth.com/articles/2010/12/07/ glonass_hits_a_snag05184.html (dostęp: 20.03.2018).

Chengzhi L., The Chinese GNSS-System development and policy analysis, „Space Policy” 29, 2013, nr 1.

China Agree on Joint Use of GLONASS, BeiDou Navigation Systems, http://tass.com/non-political/793687 (dostęp: 17.03.2018).

China to Set Up Joint Venture to Promote Satellite Navigation Services, http://tass.com/non-political/759729 (dostęp: 16.03.2018).

Cooperation Agreement on a Civil Global Navigation Satellite System (GNSS) - GALILEO between the European Community and Its Member States and the People's Republic of China, Beijing, 30 października 2003, http://ec.europa.eu/world/agreements/prepareCreateTreatiesWorkspace/treatiesGeneralData.do ?step $=0 \&$ redirect $=$ true \& treat $y I d=9226$ (dostęp: 19.05.2010).

Development of BeiDou Navigation Satellite System (BDS) - A System Update Report (2017-2018), Dr Jun Shen Deputy Director International Cooperation Centre China Satellite Navigation Office (CSNO), https:// www.gps.gov/cgsic/meetings/2017/shen.pdf (dostęp: 23.05.2018).

Differences between BeiDou-3 and the Previous Two Generations of BeiDou Satellites, http://en.chinabeidou. gov.cn/c/772.html (dostęp: 24.05.2018).

Differential for GLONASS-BeiDou, http://www.rin.org.uk/NewsItem/4832/Differential-for-GLONASS-BeiDou (dostęp: 17.03.2018).

EU and Russia Join Forces and Sign Cooperation Agreement, http://europa.eu/rapid/press-release_IP-06297_en.htm (dostęp: 15.03.2018).

EU-US Cooperation on Satellite Navigation, Working Group C, Combined Performances for Open GPS/ GALILEO Receivers, Final version, 19 lipca 2010, https://www.gps.gov/policy/cooperation/europe/2010/ working-group-c/combined-open-GPS-Galileo.pdf (dostęp: 21.05.2018).

EU-US Cooperation on Satellite Navigation, Working Group C, Combined Performances for SBAS Receivers Using WAAS and EGNOS, Final version, 19 lipca 2010, https://www.gps.gov/policy/cooperation/ europe/2010/working-group-c/combined-WAAS-EGNOS.pdf (dostęp: 21.05.2018).

FAQ, https://www.gsa.europa.eu/european-gnss/galileo/faq\#constellation (dostęp: 21.03.2018).

Fiederalnaja celewaja programma globalnaja nawigacionnaja sistiema, http://www.gpssoft.ru/fcp_glonass. html (dostęp: 12.05.2018).

Galileo Begins Serving, http://www.esa.int/Our_Activities/Navigation/Galileo_begins_serving_the_globe (dostęp: 20.03.2018).

Galileo Satellites Go into Wrong Orbit, European Space Agency Says, https://astronaut.com/galileo-satellitesgo-wrong-orbit-european-space-agency-says/ (dostęp: 15.03.2018).

Ghitis F., A Russian Satellite-Tracking Facility in Nicaragua Raises Echoes of the Cold War, https://www.worldpoliticsreview.com/articles/22385/a-russian-satellite-tracking-facility-in-nicaragua-raises-echoes-ofthe-cold-war (dostęp: 15.03.2018).

Gibbons G., GPS, GLONASS, Galileo, Compass: What GNSS Race? What Competiton?, http://www.insidegnss.com/node/1389 (dostęp: 13.03.2018). 
GNSS Market Report, European Global Navigation Satellite System Agency, 2017, nr 5, https://www.gsa. europa.eu/system/files/reports/gnss_mr_2017.pdf (dostęp: 1.04.2018).

Gruszczyński M., Jak wyłączyć GPS?, http://kosmonauta.net/2018/03/jak-wylaczyc-gps/ (dostęp: 4.04.2018).

International Committee on Global Navigation Satellite Systems, http://www.unoosa.org/oosa/en/ourwork/ icg/icg.html (dostęp: 13.03.2018).

International Committee on Global Navigation Satellite Systems, http://www.unoosa.org/oosa/en/ourwork/ $\mathrm{icg} / \mathrm{members.html} \mathrm{(dostęp:} \mathrm{13.03.2018).}$

International Cooperation, https://www.gps.gov/policy/cooperation/ (dostęp: 13.03.2018).

Januszewski J., Systemy satelitarne GPS, Galileo i inne, Wydawnictwo Naukowe PWN, Warszawa 2007.

Joint Statement on Civil Signal Compatibility and Interoperability between the Global Positioning System (GPS) and BeiDou Navigation Satellite System (BDS), https://www.gps.gov/policy/cooperation/china/2017joint-statement/ (dostęp: 15.03.2018).

Joint Statement on Galileo and GPS Signal Optimization by the European Commission (EC) and the United States (US), https://www.gps.gov/policy/cooperation/europe/2006/joint-statement/ (dostęp: 14.03.2018).

Joint Statement on the U.S. Global Positoning System (GPS) and the Russian Global Navigation Satellite System (GLONASS), https://www.gps.gov/policy/cooperation/russia/2004-joint-statement/ (dostęp: 14.03.2018).

Joint Statement United States-European Union GPS-Galileo Working Group “B” on Trade \& Civil Applications U.S. Department of Commerce, Washington, https://www.gps.gov/policy/cooperation/europe/2007/ working-group-b/ (dostęp: 14.03.2018).

Joint Statement U.S. and EU Announce Improved Performance from Receivers Using both GPS and Galileo Combined Performance, https://www.gps.gov/policy/cooperation/europe/2010/working-group-c/ (dostęp: 14.03.2018).

Joint Statement U.S.-China Civil Global Navigation Satellite Systems (GNSS) Cooperation, Beijing 2014, https://www.gps.gov/policy/cooperation/china/2014-joint-statement/ (dostęp: 15.03.2018).

Kobierecka A., Szanghajska Organizacja Współpracy jako jedna z form wielopłaszczyznowej współpracy Rosji i Chińskiej Republiki Ludowej, „Athenaeum. Polskie Studia Politologiczne” 54, 2017, nr 2.

Lindström G., Gasparini G., The Galileo satellite system and its security implications, „Occasional Paper. Institute for Security Studies" kwiecień 2003, nr 44.

Meeting of the International Committee on Global Navigation Satellite Systems (Vienna, 1-2 listopada 2006), http://www.unoosa.org/pdf/reports/ac105/AC105_879E.pdf (dostęp: 17.05.2018).

Miller J., Russia to 'Restrict' US-Run GPS Satellites, http://www.bbc.com/news/technology-27662580 (dostęp: 15.03.2018).

Moltz J.C., Asia's Space Race: National Motivations, Regional Rivalries, and International Risks, Columbia University Press, New York 2012.

Myszona-Kostrzewa K., Nawigacja satelitarna w świetle prawa międzynarodowego, Stowarzyszenie Absolwentów Wydziału Prawa i Administracji UW, Warszawa 2011.

Narkiewicz J., GPS i inne satelitarne systemy nawigacyjne, Wydawnictwo Komunikacji i Łączności, Warszawa 2007.

National Defense Authorization Act for Fiscal Year 2014, https://www.gpo.gov/fdsys/pkg/PLAW-113publ66/ pdf/PLAW-113publ66.pdf\#page=273 (dostęp: 19.05.2018).

National Space Policy of United States, 28 czerwca 2010, https://www.gps.gov/policy/docs/2010/ (dostęp: 14.03.2018).

Pellerin C., United States Updates Global Positioning System Technology. New GPS Satellite Ushers in a Range of Future Improvements, https://web.archive.org/web/20080129150600/http://www.america.gov/st/ washfile-english/2006/February/20060203125928lcnirellep0.5061609.html (dostęp: 20.03.2018).

Polkowska M., Prawo kosmiczne w obliczu nowych problemów współczesności, Liber, Warszawa 2009.

Razrabotcziki objawili o zawerszenni cozdania glonass, https://lenta.ru/news/2015/12/07/glonass/ (dostęp: 12.03.2018). 
Revised Maritime Policy and Requirements for a Future Global Navigation Satellite System (GNSS), Resolution A.915(22), 29 listopada 2001.

Rezolucja Parlamentu Europejskiego z dnia 8 czerwca 2016 r. w sprawie zdolności polityki bezpieczeństwa i obrony do działania w przestrzeni kosmicznej (2015/2276 (INI)), http://www.europarl.europa.eu/sides/ getDoc.do?pubRef=-//EP//TEXT+TA+P8-TA-2016-0267+0+DOC+XML+V0//PL (dostęp: 12.03.2018).

Rezolucja Parlamentu Europejskiego z dnia 12 września 2017 r. w sprawie strategii kosmicznej dla Europy (2016/2325 (INI)), http://www.europarl.europa.eu/sides/getDoc.do?pubRef=-//EP//TEXT+TA+P8-TA-2017-0323+0+DOC+XML+V0//PL (dostęp: 12.03.2018).

Russia-China Project Committee on Important Strategic Cooperation in Satellite Navigation, https://www. glonass-iac.ru/en/AboutIAC/silkroad2017.php (dostęp: 18.03.2018).

Russia to Place GLONASS Monitoring Stations in China, http://tass.com/non-political/759171 (dostęp: 16.03.2018).

Russia Turns IGS Data Back on - Sort of, http://gpsworld.com/russia-turns-igs-data-back-on-sort-of/ (dostęp: 15.03.2018).

Ryzenko J., Kształtowanie się europejskiej polityki kosmicznej, „Stosunki Międzynarodowe” 2005, nr 1-2.

Selding P. de, Europe, China at Impasse on Satellite Navigation Overlap, http://spacenews.com/europechina-impasse-satellite-navigation/ (dostęp: 31.03.2018).

Selding P. de, Galileo Faces More Delays, New Challenges from China, http://spacenews.com/galileo-facesmore-delays-new-challenges-china/ (dostęp: 31.03.2018).

Sitruk A., Serge P., The governance of Galileo, „European Space Institute Report” styczeń 2017, nr 62, https:// espi.or.at/publications/espi-public-reports (dostęp: 15.03.2018).

Słomczyńska I., Europejska polityka kosmiczna, Wydawnictwo UMCS, Lublin 2017.

Smolik B., Unia Europejska w obliczu głównych wyzwań polityki kosmicznej, „Wrocławskie Studia Politologiczne" 2008, nr 9.

The Space Millennium: Vienna Declaration on Space and Human Development, http://www.unoosa.org/ pdf/reports/unispace/viennadeclE.pdf (dostęp: 17.05.2018).

Statement by the President Regarding the United States' Decision to Stop Degrading Global Positioning System Accuracy, https://clintonwhitehouse3.archives.gov/WH/EOP/OSTP/html/0053_2.html (dostęp: 10.05.2018).

System Nawigacyjny Galileo. Aspekty strategiczne, naukowe i techniczne, Wydawnictwo Komunikacji i Łączności, Warszawa 2006.

Turczyński P., European Satellite Navigation System „Galileo”, [w:] European Union as a Global Actor. Political Integration: Identity Issues and Foreign Policy, red. J. Dyduch, M. Michalewska-Pawlak, R. Murphy, Oficyna Wydawnicza Aspra, Warszawa 2014.

United States-Russian Federation. GPS/GLONASS Interoperability and Compatibility Working Group (WG-1). Joint Statement, https://www.gps.gov/policy/cooperation/russia/2006-working-group-1/ (dostęp: 14.03.2018).

US Warns against European Satellite System, http://news.bbc.co.uk/2/hi/europe/1718125.stm (dostęp: 18.05.2018).

Valasek T., Galileo's strategic' Role, [w:] C. Bildt et al., Europe in Space, Centre for European Reforms, London 2004.

Verger F., Sourbés-Verger I., Ghirardi R., The Cambridge Encyclopedia of Space. Missions, Applications and Exploration, Cambridge University Press, Cambridge 2003.

Wang B., China Will Make BeiDou Navigation Satellite System Available to Global Users by 2020, https:// www.nextbigfuture.com/2016/06/china-will-make-beidou-navigation.html (dostęp: 5.07.2018).

The Way Forward: 10 Years of Achievement 2005-2015, International Committee on Global Navigation Satellite Systems, http://www.unoosa.org/res/oosadoc/data/documents/2016/stspace/stspace67_0_html/ st_space_67E.pdf (dostęp: 15.03.2018). 


\section{Global navigation satellite systems. An example of competition or cooperation between great powers?}

Keywords: satellite navigation systems, space policy, competition, Galileo, GPS

\section{Summary}

The objective of this article is to answer the question whether we currently deal with closer cooperation or rather with competition in the field of Global Navigation Satellite Systems. The author proves that both competition and cooperation are visible in the field of global satellite navigation, which when perceived from numerous perspectives do not have to be mutually exclusive. Cooperation usually results from rational economic calculation. Competition may be connected with factors of an economic, strategic and in particular military nature. Militarization of space is in itself a strongly conflictogenic element which may be confirmed by relationships in the field of GNSS. Particularly many conflicts result in the problem of compatibility of coded signals associated with defence and security. 